Abstracta Iranica Abstracta Iranica

Revue bibliographique pour le domaine irano-aryen

Volume 40-41 | 2019

Comptes rendus des publications de 2017-2018

\title{
Judith Lerner. “Ancient Persianisms in Nineteenth- Century Iran: The Revival of Persepolitan Imagery under the Qajars"
}

\section{Olivia Ramble}

\author{
(2) OpenEdition \\ Journals \\ Édition électronique \\ URL : http://journals.openedition.org/abstractairanica/50353 \\ DOI : $10.4000 /$ abstractairanica. 50353 \\ ISBN : 1961-960X \\ ISSN : 1961-960X \\ Éditeur : \\ CNRS (UMR 7528 Mondes iraniens et indiens), Éditions de l'IFRI
}

\section{Référence électronique}

Olivia Ramble, « Judith Lerner. "Ancient Persianisms in Nineteenth-Century Iran: The Revival of

Persepolitan Imagery under the Qajars" », Abstracta Iranica [En ligne], Volume 40-41 | 2019, document 8, mis en ligne le 30 octobre 2019, consulté le 19 avril 2021. URL : http://journals.openedition.org/ abstractairanica/50353 ; DOI : https://doi.org/10.4000/abstractairanica.50353

Ce document a été généré automatiquement le 19 avril 2021.

Tous droits réservés 


\section{Judith Lerner. "Ancient Persianisms in Nineteenth-Century Iran: The Revival of Persepolitan Imagery under the Qajars"}

Olivia Ramble 


\section{RÉFÉRENCE}

Judith Lerner. “Ancient Persianisms in Nineteenth-Century Iran: The Revival of Persepolitan Imagery under the Qajars" in Rolf Strootman, Miguel John Versluys (eds.). Persianism in Antiquity. Stuttgart: Franz Steiner, 2017, p. 107-120 (Oriens et Occidens 25)

1 L'A. tente d'expliquer la résurgence soudaine de l'iconographie achéménide notamment des motifs persépolitains - à la période qajare tardive. Jusqu'alors, les modèles sassanides (scènes d'investiture ou de chasse royale) incarnant les topoi de l'art perse, se retrouvaient sur les textiles et la céramique-ainsi que sur les bas-reliefs à partir de Fath 'Ali Shah (1772-1834) qui manifeste un regain d'intérêt pour cette forme artistique monumentale. Selon l'A. la renaissance de motifs achéménides est déclenchée par la traduction de l'inscription de Darius à Bisotūn entreprise par Henry C. Rawlinson en 1836, vivement soutenu par Mohammad Shah (1808-1848) : le passé préislamique de l'Iran se racontait enfin du point de vue iranien, au-delà des légendes du Shāhnāmeh, à une époque où la dynastie Qajar était soucieuse d'affirmer la modernité d'un pays dotée d'une tradition nationale et de frontières ancrées dans l'histoire. Pour l'A. cette réappropriation du passé achéménide a été le "persianisme » catalyseur de la création de l'état moderne iranien : un outil puissant repris à profit par Reza Shah pour légitimer sa prise de pouvoir et fonder la nouvelle dynastie des Pahlavis.

\section{AUTEURS}

\section{OLIVIA RAMBLE}

Doctorante EPHE, Mondes iranien et indien, Paris 